\title{
The Effect of Saturated Fatty Acids on Methanogenesis and Cell Viability of Methanobrevibacter ruminantium
}

\author{
Xuan Zhou, ${ }^{1}$ Leo Meile, ${ }^{2}$ Michael Kreuzer, ${ }^{1}$ and Johanna O. Zeitz ${ }^{1}$ \\ ${ }^{1}$ ETH Zurich, Institute of Agricultural Sciences, Universitaetstrasse 2, 8092 Zurich, Switzerland \\ ${ }^{2}$ ETH Zurich, Institute of Food, Nutrition and Health, Schmelzbergstrasse 7, 8092 Zurich, Switzerland
}

Correspondence should be addressed to Johanna O. Zeitz; j.zeitz@gmx.de

Received 23 December 2012; Accepted 21 March 2013

Academic Editor: Yoshizumi Ishino

Copyright (C) 2013 Xuan Zhou et al. This is an open access article distributed under the Creative Commons Attribution License, which permits unrestricted use, distribution, and reproduction in any medium, provided the original work is properly cited.

\begin{abstract}
Saturated fatty acids (SFAs) are known to suppress ruminal methanogenesis, but the underlying mechanisms are not well known. In the present study, inhibition of methane formation, cell membrane permeability (potassium efflux), and survival rate (LIVE/DEAD staining) of pure ruminal Methanobrevibacter ruminantium (DSM 1093) cell suspensions were tested for a number of SFAs. Methane production rate was not influenced by low concentrations of lauric $\left(\mathrm{C}_{12} ; 1 \mu \mathrm{g} / \mathrm{mL}\right)$, myristic $\left(\mathrm{C}_{14} ; 1\right.$ and $\left.5 \mu \mathrm{g} / \mathrm{mL}\right)$, or palmitic $\left(\mathrm{C}_{16}\right.$; 3 and $5 \mu \mathrm{g} / \mathrm{mL})$ acids, while higher concentrations were inhibitory. $C_{12}$ and $C_{14}$ were most inhibitory. Stearic acid $\left(C_{18}\right)$, tested at $10-80 \mu \mathrm{g} / \mathrm{mL}$ and ineffective at $37^{\circ} \mathrm{C}$, decreased methane production rate by half or more at $50^{\circ} \mathrm{C}$ and $\geq 50 \mu \mathrm{g} / \mathrm{mL}$. Potassium efflux was triggered by SFAs $\left(\mathrm{C}_{12}=\mathrm{C}_{14}>\mathrm{C}_{16}>\mathrm{C}_{18}=\right.$ control), corroborating data on methane inhibition. Moreover, the exposure to $\mathrm{C}_{12}$ and $\mathrm{C}_{14}$ decreased cell viability to close to zero, while $40 \%$ of control cells remained alive after $24 \mathrm{~h}$. Generally, tested SFAs inhibited methanogenesis, increased cell membrane permeability, and decreased survival of M. ruminantium in a dose- and time-dependent way. These results give new insights into how the methane suppressing effect of SFAs could be mediated in methanogens.
\end{abstract}

\section{Introduction}

Methane $\left(\mathrm{CH}_{4}\right)$ as a potent greenhouse gas is among the most important drivers of compositional changes of atmospheric gas and thus global warming [1]. Agricultural $\mathrm{CH}_{4}$ emissions account for about $50 \%$ of total $\mathrm{CH}_{4}$ from anthropogenic sources, where the single largest one is from enteric fermentation in ruminant livestock [2]. Methane is generated by a subgroup of the Archaea, the methanogens, which are, in the ruminant's fore-stomach (rumen), dominated by Methanobrevibacter [3]. At undisturbed rumen function, proteins and polymeric carbohydrates as main components of the diet are degraded by microorganisms and fermented mainly to volatile fatty acids (VFAs), ammonia, hydrogen $\left(\mathrm{H}_{2}\right)$, and carbon dioxide $\left(\mathrm{CO}_{2}\right)$. Ruminal methanogens primarily utilize $\mathrm{H}_{2}$ as energy source to reduce $\mathrm{CO}_{2}$ to $\mathrm{CH}_{4}$ in a series of reactions that are coupled to ATP synthesis $[4,5]$. As $\mathrm{CH}_{4}$ cannot be utilized in the metabolism of the animal, ruminal methanogenesis also impairs feed conversion efficiency and represents a significant waste of energy ( $2 \%$ to $12 \%$ of energy intake; [6]).
Therefore, inhibition of ruminal methanogenesis should be approached by various interventions. Among the most effective are dietary medium- and long-chain saturated fatty acids (SFAs). Nonesterified lauric acid $\left(\mathrm{C}_{12}\right)$ was reported to have a particularly high potential in suppressing ruminal methanogenesis, followed by myristic acid $\left(\mathrm{C}_{14}\right)$ [7-9]. By contrast, long-chain SFAs (LCFAs) such as palmitic acid $\left(\mathrm{C}_{16}\right)$ and stearic acid $\left(\mathrm{C}_{18}\right)$ were not effective in suppressing ruminal methanogenesis in vitro $[7,10]$. The production of $\mathrm{CH}_{4}$ by pure, growing, cultures of $M$. ruminantium, a dominant ruminal methanogen [3], was found to be inhibited by the addition of unsaturated $[11,12]$ and saturated mediumchain $\left(\mathrm{C}_{12}-\mathrm{C}_{16}\right.$; $\left.[12]\right)$ fatty acids. When testing the nonruminal methanogens Methanothermobacter thermoautotrophicus and Methanococcus voltae, $\mathrm{C}_{12}$ and $\mathrm{C}_{14}$ were found to inhibit methanogenesis as well [13]. However, systematic studies on dose-response relationships with SFAs on methanogenesis in pure ruminal methanogen cultures are missing. Besides, it is unclear why long-chain SFAs do not inhibit methanogenesis and if this is related to the low solubility of these longchain SFAs at temperatures below $40^{\circ} \mathrm{C}[13,14]$. Furthermore, 
although fatty acids (FAs) are known to have antimicrobial and cytotoxic properties [15] and are used by a wide range of organisms like humans [16], molluscs [17], and brown algae [18] to defend against pathogens, the mechanisms which lead to the inhibition effect are still not definitely known. Several mechanisms have been proposed [15]. The primary target of the action seems to be the microbial cell membrane and various essential processes that occur within and at the membrane [15]. Fatty acids, including $\mathrm{C}_{12}, \mathrm{C}_{14}, \mathrm{C}_{16}$, and $\mathrm{C}_{18}$, have been shown to pass protein-free phospholipid bilayers in their unionized form [19]. Saturated and unsaturated fatty acids may be adsorbed by bacterial cell membranes [20], damage the bacterial cell membrane as determined by loss of potassium $\left(\mathrm{K}^{+}\right)$[21], ATP, and proteins [16] and by electron microscopy $[22,23]$, and play a role in cell death $[22,24,25]$. As the composition of the cell envelope of methanogens is fundamentally different from the bacterial cell envelope, and the methanogens are phylogenetically and physiologically distinct from all other cell types [26], the mechanisms of FA action on methanogens may differ from that valid for other organisms. However, since the methanogen cell envelope normally acts as a diffusion barrier between the cytoplasm and the extracellular medium, it might also represent a key point for the identification of inhibitor targets. Therefore, we hypothesized that membrane integrity is disturbed and leakage of cell metabolites including inorganic ions such as $\mathrm{K}^{+}$occurs through the interaction of the SFA with the cell membrane lipids and that this results in an impaired cell survival. Like in most prokaryotes, $\mathrm{K}^{+}$is accumulated in the cytoplasm of methanogens in exchange for $\mathrm{Na}^{+}$[27].

In the present study, pure cultures of $M$. ruminantium were treated with pure nonesterified SFAs in order to exclude all confounding factors such as interactions between feed, minerals, and microbes occurring in vivo or with rumen fluid in vitro. The aims of the present study were (i) to investigate the relationship between SFA type and dosage and the inhibition of methanogenesis in nongrowing cells, that is, cell suspensions, and (ii) to get first insights into the modes of action underlying in this process. In detail, $\mathrm{K}^{+}$efflux was used as an indicator of membrane integrity. Finally, cell survival was monitored using the LIVE/DEAD BacLight Kit which has been successfully used in Archaea before [28, 29].

\section{Materials and Methods}

2.1. Strain and Growth Conditions. A pure culture of M. ruminantium M1 (DSM 1093) was obtained from the "Deutsche Sammlung von Mikroorganismen und Zellkulturen," Braunschweig, Germany. It was anaerobically cultivated in the strain-specific cultivation medium 119 prepared according to DSMZ (http://www.dsmz.de) in $120 \mathrm{~mL}$ serum bottles, which were sealed with butyl rubber stoppers $(20 \mathrm{~mm}$ size; 2048 11800 , Bellco, Vineland, USA) and aluminum seals (204811020, Bellco). Reagents for the media were dissolved in boiled oxygen-deprived distilled water and stirred on a magnetic stirrer overnight in an anaerobic chamber (Coy Laboratory Products, Grasslake, USA). Heat stable solutions of media ingredients were sterilized in a batch autoclave (Sauter, Belimed Sauter AG, Sulgen, Switzerland) for $20 \mathrm{~min}$ at $121^{\circ} \mathrm{C}$.
Heat susceptible solutions, that is, vitamins, sodium formate, and SFA, were filtrated through a $0.2 \mu \mathrm{m}$ Minisart-plus filter (Sartorius AG, Göttingen, Germany). Ruminal fluid was obtained from a rumen-cannulated cow, filtered through four layers of medicinal gauze (REF 200137, Novamed, Jerusalem, Israel) and then centrifuged twice for $15 \mathrm{~min}$ at $4,000 \times \mathrm{g}$ (Varifuge K, Heraeus, Osterode, Germany). The supernatant was adjusted to $\mathrm{pH} 7.0$ with $\mathrm{HCl}$ and $\mathrm{NaOH}$, gassed with $\mathrm{N}_{2}$ to an atmospheric pressure of $150 \mathrm{kPa}$, autoclaved, and stored at $-20^{\circ} \mathrm{C}$ for up to 6 months, before being used to prepare the media. Aliquots of the prepared medium were filled into 250-mL bottles, closed with rubber septa, gassed with $\mathrm{N}_{2}$ to atmospheric pressure of $250 \mathrm{kPa}$, autoclaved, and stored either at $4^{\circ} \mathrm{C}$ for 8 weeks or at $-20^{\circ} \mathrm{C}$ for up to 6 months before being used. M. ruminantium was grown under atmospheric pressure of $250 \mathrm{kPa}$ of a $\mathrm{CO}_{2} / \mathrm{H}_{2}$ mixture (20:80) (Pangas AG, Dagmarsellen, Switzerland). The gas mixture in the headspace was renewed every $24 \mathrm{~h}$ and $3 \mathrm{~mL}$ precultures were transferred to $27 \mathrm{~mL}$ fresh medium every four days. The culture bottles were incubated in horizontal position in an incubation shaker (Incu Shaker $10 \mathrm{~L}$, Benchmark, Korea) at $37^{\circ} \mathrm{C}$ with a shaking speed of $150 \mathrm{rpm}$. Growth of the cultures was monitored by recording $\mathrm{CH}_{4}$ production, gas consumption, and optical density. A volume of $0.15 \mathrm{~mL}$ of gas was collected from the headspace of the cultivation bottle with a gas-tight syringe (Hamilton, model 1725/RN 250 mL, Fisher Scientific AG, Wohlen, Switzerland), and its $\mathrm{CH}_{4}$ concentration was analyzed with a gas chromatograph (model 6890N, Agilent Technologies, Santa Clara, CA, USA) equipped with a flame ionization detector operated at $250^{\circ} \mathrm{C}$ and a $234 \mathrm{~mm} \times 23 \mathrm{~mm}$ column (80/100; 166 mesh; Porapak Q, Fluka Chemie AG, Buchs, Switzerland). Overpressure in the cultivation bottles was detected with a manometer (GDH 200-13, Greisinger Electronic GmbH, Regenstauf, Germany). One milliliter of culture liquid was collected in acrylic absorption cuvettes ( $1 \mathrm{~cm}$ path length; (VWR, Leuven, Germany)), and its optical density was measured at $600 \mathrm{~nm}\left(\mathrm{OD}_{600}\right)$ with a UV-160A recording spectrophotometer (Shimadzu, Kyoto, Japan). The growth phases distinguished were lag, exponential, stationary, and death phase. Prior to each experiment, methanogens were inoculated into fresh medium with $3 \mathrm{~mL}$ of pre-culture in their early to mid-exponential growth phase.

2.2. Experiment 1. Lauric acid, $C_{14}, C_{16}$, and $C_{18}(\geq 97 \%$ purity) were obtained from Sigma-Aldrich, Buchs, Switzerland, to be used as experimental supplements. Stock solutions were prepared by dissolving the SFA in the sterile-filtered solvent dimethyl sulfoxide (DMSO) (Sigma-Aldrich) to reach concentrations of $1,3,5,10$, and $30 \mathrm{mg} / \mathrm{mL}\left(\mathrm{C}_{12}\right.$ to $\left.\mathrm{C}_{16}\right)$ as well as 50 and $80 \mathrm{mg} / \mathrm{mL}\left(\mathrm{C}_{18}\right)$. They were stored at room temperature before supplementation. The $\mathrm{C}_{18}$ solution to be applied later at $50^{\circ} \mathrm{C}$ was heated to $50^{\circ} \mathrm{C}$ before use.

As $\mathrm{OD}_{600}$ was used to estimate cell dry matter (DM) concentration in growing cultures prior to harvesting, a regression line between $\mathrm{OD}_{600}$ and cell $\mathrm{DM}$ concentration was established before the start of the experiment. Seventeen bottles of medium were prepared and inoculated with $M$. ruminantium as described before. From three bottles each, $21 \mathrm{~mL}$ of culture liquid were collected after 24, 48, 53, 
72,77 , and $96 \mathrm{~h}$ covering the development from the early exponential growth phase to the stationary phase. Thereof, $1 \mathrm{~mL}$ was used for measurement of $\mathrm{OD}_{600}$, and $20 \mathrm{~mL}$ was dried at $70^{\circ} \mathrm{C}$ to constant weight in a $50 \mathrm{~mL}$ Falcon tube after the wet weight had been recorded in order to calculate culture DM content. The regression curve established from in total $17 \mathrm{OD} / \mathrm{DM}$ pairs (OD range: 0.348 to 0.986 ) was linear and reads $\mathrm{DM}(\mathrm{mg} / \mathrm{mL})=7.6092 \times \mathrm{OD}_{600}+0.4754\left(R^{2}=0.95\right)$. This relationship was used to adjust and equalize cell DM concentration in cell suspensions.

In order to prepare the experimental cell suspensions in an anaerobic chamber, always $20 \mathrm{~mL}$ of culture were harvested in the mid-exponential growth phase and transferred to two $50 \mathrm{~mL}$ sterilized Falcon tubes and centrifuged for $10 \mathrm{~min}$ at $3,000 \times \mathrm{g}$. The supernatant was discarded and the pellet was washed twice with an autoclaved phosphate buffer of $\mathrm{pH} 6.8$ containing $0.025 \mathrm{M} \mathrm{KH}_{2} \mathrm{PO}_{4}, 0.025 \mathrm{M}$ $\mathrm{K}_{2} \mathrm{HPO}_{4}, 0.5 \mathrm{mM}$ titanium citrate, $0.1 \mathrm{M} \mathrm{NaCl}$, and $1 \mathrm{mM}$ $\mathrm{MgCl}_{2}$ [30]. Titanium citrate was prepared according to Jones and Pickard [31], by anaerobically adding $5 \mathrm{~mL}$ of a $15 \%$ titanium(III) chloride solution (Merck Millipore, Darmstadt, Deutschland) to $50 \mathrm{~mL}$ of $0.2 \mathrm{M}$ sodium citrate solution, adjusting with a saturated sodium carbonate solution to $\mathrm{pH} 7$, gassing the bottle with $\mathrm{N}_{2}$, followed by autoclaving. Syringes were used for all withdrawals. After washing, the cell pellet was then resuspended in the same buffer to a final concentration of $6 \mathrm{mg}$ cell $\mathrm{DM} / \mathrm{mL}$ adjusted with the help of the regression line relating $\mathrm{OD}$ and culture DM concentration. Under anaerobic condition, $1 \mu \mathrm{L}$ of the differently concentrated SFA stock solutions was added to $999 \mu \mathrm{L}$ cell suspensions in $25 \mathrm{~mL}$ serum bottles to reach concentrations of $1,3,5,10$, and $30 \mu \mathrm{g} / \mathrm{mL}$ of $\mathrm{C}_{12}, \mathrm{C}_{14}$, and $\mathrm{C}_{16}$ as well as 50 and $80 \mu \mathrm{g} / \mathrm{mL}$ of $\mathrm{C}_{18}$. The bottles were sealed with rubber stoppers (size 18D, 203018; Glasgerätebau Ochs, Lenglern, Germany), gassed to atmospheric pressure of $250 \mathrm{kPa}$ with a $\mathrm{CO}_{2} / \mathrm{H}_{2}$ mixture $(20: 80)$ and stored on ice waiting for incubation start by putting into a waterbath (Julabo shake Temp, Merck, Switzerland) at set intervals due to time needed for GC measurement ( $3.2 \mathrm{~min} / \mathrm{sample})$. Cell suspensions were incubated at $37^{\circ} \mathrm{C}$ and $50^{\circ} \mathrm{C}$ (only $\mathrm{C}_{18}$ ) shaking suspensions at $150 \mathrm{rpm}$. Finally, suspensions where no SFA had been added were supplemented with either $1 \mu \mathrm{L} / \mathrm{mL}$ DMSO, equal to the DMSO concentration in treatment groups (control group) or with $1 \mu \mathrm{L} / \mathrm{mL}$ of the buffer (blank group). The $\mathrm{CH}_{4}$ concentration (mol \%) was determined by gas chromatography after $1,2,5$, and $24 \mathrm{~h}$ had passed. The $\mathrm{CH}_{4}$ production rate $\left(\mu \mathrm{mol} \mathrm{CH}_{4} / \mathrm{mg}\right.$ cell DM per min) was calculated from bottle head space gas volume and the volume of $\mathrm{CH}_{4}$ produced. The amount of gas present in the bottles at the start of the experiment were set to $0.0023 \mathrm{~mol}$ as calculated from using the ideal gas law ( $n=p \times V / R \times T$, where $p$ is the sum of the overpressure of the gas in the bottle $(150000 \mathrm{~Pa})$ and the standard air pressure ( $96600 \mathrm{~Pa}$ for Zurich), $V$ is the volume of the gas $=24 \times$ $10^{-6} \mathrm{~m}^{3}, n$ is the amount of gas in the bottle in mol, $T$ is the temperature of the gas $=309.15 \mathrm{~K}$, and $R$ is the ideal gas constant $\left.=8.314 \mathrm{~J} \mathrm{~K}^{-1} \mathrm{~mol}^{-1}\right)$. The amounts of $\mathrm{CH}_{4}$ produced in each bottle $(Y$; in mol) were calculated considering the stoichiometry of methanogenesis from $\mathrm{H}_{2}$ and $\mathrm{CO}_{2}$, that is, that $5 \mathrm{~mol}$ of gas are consumed to produce $1 \mathrm{~mol}^{\text {of }} \mathrm{CH}_{4}$ meaning $Y /(0.0023-4 \times Y)=\operatorname{mol} \% \mathrm{CH}_{4}(X / 100)$ and therefore $Y=0.0023 X /(100+4 X)$.

For each SFA, a minimum of two independent cell suspension incubations were performed with freshly grown $M$. ruminantium culture, each performed at least in triplicate.

2.3. Experiments 2 and 3. Cells were harvested as described before and resuspended to a final concentration of $6 \mathrm{mg}$ cell $\mathrm{DM} / \mathrm{mL}$ in $\mathrm{K}^{+}$-free buffer containing $0.025 \mathrm{M}\left(\mathrm{NH}_{4}\right)_{2} \mathrm{HPO}_{4}$, $0.025 \mathrm{M} \mathrm{NH}_{4} \mathrm{H}_{2} \mathrm{PO}_{4}, 0.01 \mathrm{M} \mathrm{NaCl}, 1 \mathrm{mM} \mathrm{MgCl}_{2}$, and $0.5 \mathrm{mM}$ titanium citrate. Two resting cell suspension experiments were performed at $37^{\circ} \mathrm{C}$ as described before, and in Experiment 2, $\mathrm{C}_{12}$ was supplemented to final concentrations of 10,15 and $30 \mu \mathrm{g} / \mathrm{mL}$, and in Experiment $3, C_{12}, C_{14}$, $\mathrm{C}_{16}$ and $\mathrm{C}_{18}$ were added to reach a final concentration of $10 \mu \mathrm{g} / \mathrm{mL}$. After $3 \mathrm{~h}$ and $24 \mathrm{~h}$ of incubation, $300 \mu \mathrm{L}$ of cell suspension were transferred to a $2 \mathrm{~mL}$ centrifuge tube inside the anaerobic chamber, centrifuged at $10,000 \times \mathrm{g}$ for $10 \mathrm{~min}$, and the $\mathrm{K}^{+}$concentration in the supernatant was analyzed by Inductively Coupled Plasma-Optical Emission Spectrometer (715-ES Radial ICP OES, Varian, Canada). A stock solution containing $1 \mathrm{mg} / \mathrm{L} \mathrm{KNO}_{3}$ (Merck, Darmstadt, Germany) and $1 \% \mathrm{HNO}_{3}$ in distilled water was used to prepare a calibration curve with concentrations of $0,25,50$, 75 , and $100 \mu \mathrm{L} / \mathrm{L}$. Samples were diluted 50 -fold by using a diluter (Microlab 1000, Hanmilton, Martinsried, Germany) in $5 \mathrm{~mL}$ of total volume. The survival rate of $M$. ruminantium in cell suspensions after 3 and $24 \mathrm{~h}$ was assessed by using the LIVE/DEAD BacLight Bacterial Viability Kit for microscopy and quantitative assays (Kit L7012; Invitrogen GmbH, Darmstadt, Germany). The kit applied contained two fluorescent dyes: propidium iodide with red fluorescence penetrates cells with damaged membranes; SYTO 9 with green fluorescence accumulates only in living cells. Thus, undestroyed archaeal cells with intact membranes have green fluorescence, while cells with damaged membranes display red fluorescence. Occasionally, an intermediate ambiguous yellowish color has been observed which has been observed also in studies of others [28]. Cells showing this color have been categorized as living cells with damaged membrane but were not included into the category of living cells in the tables. Staining was performed according to the manufacturer's protocol with several modifications. An amount of $0.5 \mu \mathrm{L}$ of a $1: 1$ mixture of SYTO 9 and propidium iodide dyes was added to $100 \mu \mathrm{L}$ of cell suspension under aerobic conditions, mixed thoroughly and incubated at room temperature in the dark for $10 \mathrm{~min}$. No washing was required before staining because background fluorescence was low in this experimental system, and oxygen exposure was minimized by this way. An amount of $5 \mu \mathrm{L}$ of the stained cell suspension was trapped between a microscope slide and an $18 \mathrm{~mm}$ square cover glass. All samples were examined at 600 and 1000 times magnification using a fluorescence microscope (BX60; Olympus $\mathrm{GmbH}$, Voketswil, Switzerland) and a digital camera (FView; adapter U-CMAD, Olympus, Switzerland). Three locations on each sample were chosen and captured at random. Fluorescent micrographs (exposure time: $50 \mathrm{~ms}$ ) of the very same sample section were 
taken applying appropriate filter sets for propidium iodide (wavelengths: excitation 530-545 nm, emission $>610 \mathrm{~nm}$ ) and SYTO 9 (excitation 440-470 nm, emission 525-550 nm) and using the digital image analysis software Analysis (Soft Image System GmbH, Münster, Germany). The two false-colored images of one sample section were combined using the same software, and dead and live cells were counted with Adobe Photoshop CS5 (Adobe, San Jose, USA). Postacquisition processing involved adjustments of the brightness/contrast to optimize the visualization of live and dead cells within the images. Viability was calculated as viability $=N / N_{0} \times$ 100 , where $N_{0}$ are the total fluorescence counts and $N$ are the green fluorescence counts after $3 \mathrm{~h}$ and $24 \mathrm{~h}$ of reaction. Experiments 2 and 3 were performed in triplicate with three samples per treatment group and additionally, three samples for LIVE/DEAD staining and $\mathrm{K}^{+}$leakage determination after $3 \mathrm{~h}$.

2.4. Statistical Analysis. For Experiment 1, analysis of variance was performed using the MIXED procedure of SAS (version 9.1 of 2003; SAS Institute Inc., Cary, NC) with treatment group and time point and its interaction as fixed factors and the repeated statement to compare control and SFAsupplemented cultures at each time-point. For Experiments 2 and 3, treatment group was considered as fixed and replicate as random factor to compare $\mathrm{CH}_{4}$ inhibition rate, $\mathrm{K}^{+}$leakage and cell viability both at 3 and $24 \mathrm{~h}$. The Bonferroni correction was used for multiple comparisons among means. Differences were declared statistically significant at $P<0.05$. The results are presented as means \pm standard errors.

\section{Results}

3.1. Inhibition of Methane Production of Methanobrevibacter ruminantium by Saturated Fatty Acids as Depending on Dose in Experiment 1. All SFAs investigated influenced $\mathrm{CH}_{4}$ production by M. ruminantium in a dose-dependent way, but the extent of the effect differed (Figure 1). In Figure 1, only one of the two incubations performed per SFA is shown (the other is given as Supplementary Figure 1), but values were similar between incubations. For $\mathrm{C}_{12}$, the $\mathrm{CH}_{4}$ production rate was inhibited in a dose-dependent way with $(\mu \mathrm{g} / \mathrm{mL}) 30>10=5$ $\geq$ control $\geq 1$ (incubation 1; Figure 1(a)) and $30>10=5>1$ $=$ control (incubation 2; Supplementary Figure 1). For $\mathrm{C}_{14}$, the sequence was $30>10>1=$ control $>5$ (incubation 1 ; Figure $1(\mathrm{~b})$ ) and $30=10>1 \geq 5 \geq$ control (incubation 2). The inhibitory pattern of $\mathrm{C}_{16}$ was different from $\mathrm{C}_{12}$ and $\mathrm{C}_{14} ; \mathrm{C}_{16}$ needed more time to exert its influence: dosages of 10 and $30 \mu \mathrm{g} / \mathrm{mL}$ inhibited the $\mathrm{CH}_{4}$ production rate at $24 \mathrm{~h}$ completely (incubation 1; Figure 1(c)) or by half (incubation 2) but not at earlier time points. Lower concentrations did not inhibit $\mathrm{CH}_{4}$ production during the measurement period. $\mathrm{C}_{18}$ was not effective at $37^{\circ} \mathrm{C}$ (Figure $1(\mathrm{~d})$ ) but at $50^{\circ} \mathrm{C}$, a temperature closer to the melting point of $\mathrm{C}_{18}$ of $69^{\circ} \mathrm{C}$. At $50^{\circ} \mathrm{C}, \mathrm{C}_{18}$ decreased the $\mathrm{CH}_{4}$ production rate in a dosedependent way after $5 \mathrm{~h}$ by $55 \%$ and $68 \%$ at 10 and $30 \mu \mathrm{g} / \mathrm{mL}$, respectively (incubation 1; Figure 1(e)). At $50 \mu \mathrm{g} / \mathrm{mL}$, the $\mathrm{CH}_{4}$ production rates started to decline even earlier and were decreased by $63 \%$ and $99 \%$ at $5 \mathrm{~h}$ and $24 \mathrm{~h}$, and at $80 \mu \mathrm{g} / \mathrm{mL}$, by $52 \%, 94 \%$, and $100 \%$ at $1 \mathrm{~h}, 3 \mathrm{~h}$, and $5 \mathrm{~h}$, respectively.

3.2. Influence of Lauric Acid on Methane Production, $\mathrm{K}^{+}$ Leakage and Cell Viability in Experiment 2. In $\mathrm{K}^{+}$-free buffer, the $\mathrm{CH}_{4}$ inhibitory pattern of $\mathrm{C}_{12}$ (Table 1) was similar as compared to Experiment 1 in $\mathrm{K}^{+}$-containing buffer; concentrations of $\geq 10 \mu \mathrm{g} / \mathrm{mL}$ decreased the $\mathrm{CH}_{4}$ production rate very fast and, with $30 \mu \mathrm{g} / \mathrm{mL}$, stopped it completely after already $3 \mathrm{~h}$. A quick increase in extracellular $\mathrm{K}^{+}$concentration occurred in $\mathrm{C}_{12}$-treated groups after $3 \mathrm{~h}$ of incubation (Table 1). Especially in groups where 15 and $30 \mu \mathrm{g} / \mathrm{mL}$ was added, extracellular $\mathrm{K}^{+}$concentration reached its peak already at $3 \mathrm{~h}$ and did not increase as reaction time progressed. The viability of the M. ruminantium cells as verified using LIVE/DEAD staining at $3 \mathrm{~h}$ and $24 \mathrm{~h}$ after supplementation of 10,15 , and $30 \mu \mathrm{g} \mathrm{C}_{12} / \mathrm{mL}$ is shown in Table 1. Although methanogenesis was completely inhibited and marked $\mathrm{K}^{+}$leakage occurred in groups supplemented with 15 and $30 \mu \mathrm{g} \mathrm{C}_{12} / \mathrm{mL}$ at $3 \mathrm{~h}$, cell viability was still $27 \%$ and $29 \%$, respectively, instead of being zero. Within $24 \mathrm{~h}, \mathrm{C}_{12}$ caused more cell death.

\subsection{Influence of Saturated Fatty Acids on Methane Production,} $K^{+}$Leakage, and Cell Viability in Experiment 3. All SFAs were supplemented in the same concentration $(10 \mu \mathrm{g} / \mathrm{mL})$ in a single incubation to allow a direct comparison between SFAs (Table 2). $\mathrm{C}_{12}$ and $\mathrm{C}_{14}$ had a similar inhibitory effect on methanogenesis. Both immediately started displaying their influence. $\mathrm{C}_{16}$ needed more time and its effect was weaker than that of the former two SFAs, while $\mathrm{C}_{18}$ showed no effect at $37^{\circ} \mathrm{C}$, which was consistent with the results of Experiment 1. The patterns of methanogenesis inhibition and $\mathrm{K}^{+}$efflux were similar (Table 2). $\mathrm{C}_{12}$ and $\mathrm{C}_{14}$ also had the strongest effect of all SFAs tested in triggering $\mathrm{K}^{+}$leakage, while $\mathrm{C}_{16}$ caused lower $\mathrm{K}^{+}$efflux compared to $\mathrm{C}_{12}$ and $\mathrm{C}_{14}$, but the extracellular $\mathrm{K}^{+}$concentration was higher $(P<0.05)$ than in control (Table 2). In summary, the $\mathrm{K}^{+}$efflux was (in decreasing order): $\mathrm{C}_{12}=\mathrm{C}_{14}>\mathrm{C}_{16}>\mathrm{C}_{18}>$ control. Interestingly, $\mathrm{C}_{18}$ showed no inhibitory effect on $\mathrm{CH}_{4}$ production rate but did cause $\mathrm{K}^{+}$efflux $(+23 \%$ as compared to the control after $3 \mathrm{~h}) . \mathrm{C}_{12}$ and $\mathrm{C}_{14}$ had the strongest effect on cell viability, as $57 \%$ and $64 \%$ of the cells were categorized as dead after $3 \mathrm{~h}$, while in the $\mathrm{C}_{16}$ group only $32 \%$ of cells were dead or, as part of the cells were not red but yellow, damaged (Figure 2). At $24 \mathrm{~h}$, nearly all cells treated with $\mathrm{C}_{12}$ and $\mathrm{C}_{14}$ were dead, compared to $60 \%$ of dead cells found in the control (Table 2 and Figure 2). Also in the $\mathrm{C}_{16}$ treatment $88 \%$ of cells were dead after $24 \mathrm{~h}$, which implies that the inhibition of methanogenesis and $\mathrm{K}^{+}$efflux are somehow correlated. $\mathrm{C}_{18}$ did not cause significant extra cell death when compared to the control group.

\section{Discussion}

The antifungal and bactericidal properties of FA have been extensively investigated, and, as a generalization, the cell membrane seems to be the prime target to explain the effects 


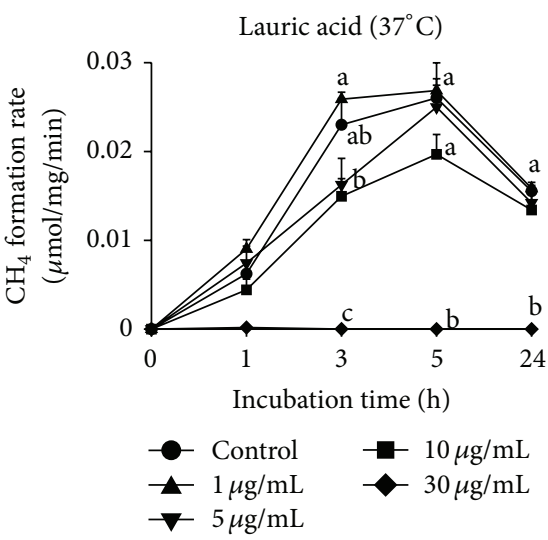

(A)

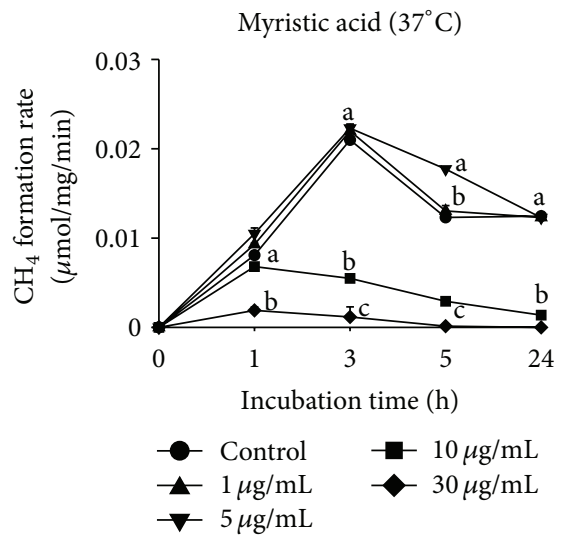

(B)

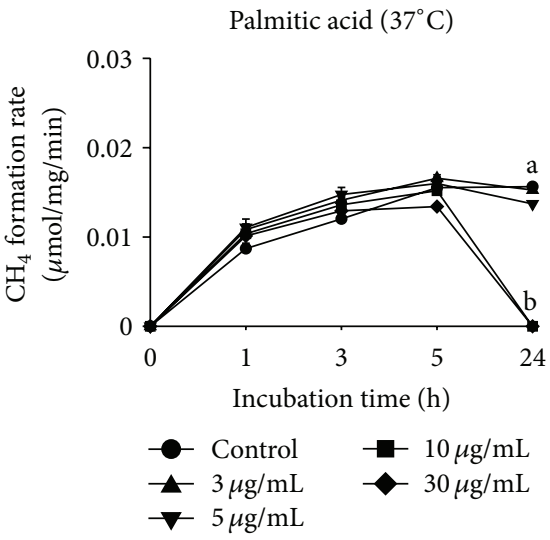

(C)

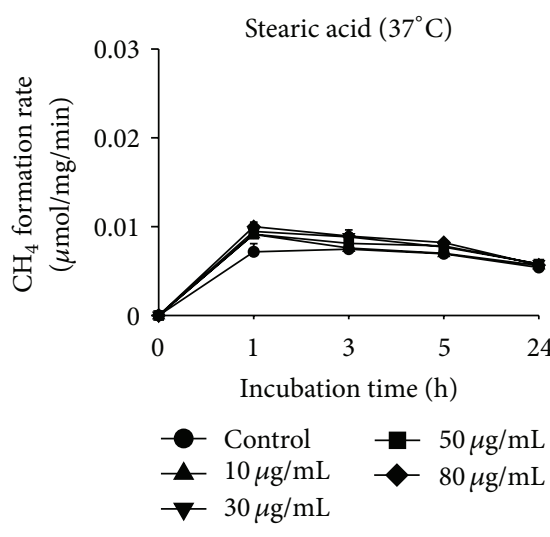

(D)

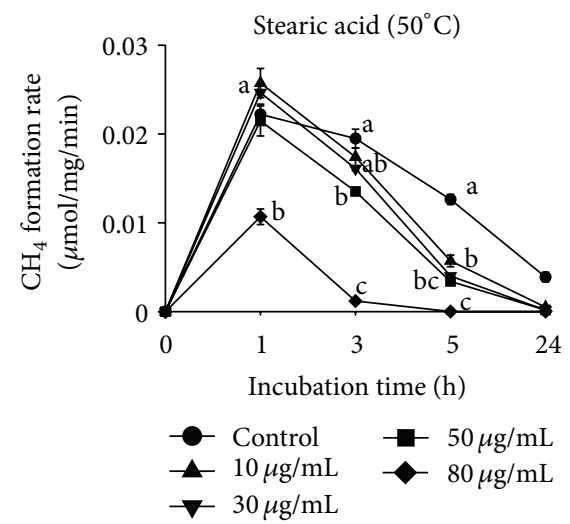

(E)

FIGURE 1: Methane production rate $(\mu \mathrm{mol} / \mathrm{mg}$ cell $\mathrm{DM} / \mathrm{min})$ in cell suspensions of M. ruminantium in $\mathrm{K}^{+}$-containing buffer $(n=3)$ in response to supplementation of different concentrations of lauric acid (A), myristic acid (B), palmitic acid (C), and stearic acid (D) at $37^{\circ} \mathrm{C}$ and of stearic acid at $50^{\circ} \mathrm{C}(\mathrm{E})$ (Experiment 1). Means within time point with unequal letters (a,b) are different at $P<0.05$. Bars represent standard errors.

TABLE 1: Methane inhibition rate, $\mathrm{K}^{+}$efflux, and cell viability in cell suspensions treated with $\mathrm{C}_{12}$ in different concentrations in Experiment 2 ( $n=3$; means \pm standard error).

\begin{tabular}{lcccccc}
\hline Time & \multicolumn{3}{c}{$3 \mathrm{~h}$} & \multicolumn{2}{c}{$24 \mathrm{~h}$} \\
Treatment & $\mathrm{K}^{+}(\mathrm{mg} / \mathrm{L})$ & $\mathrm{CH}_{4}$ inhibition $(\%)^{\mathrm{1}}$ & Cell viability $(\%)^{2}$ & $\mathrm{~K}^{+}(\mathrm{mg} / \mathrm{L})$ & $\mathrm{CH}_{4}$ inhibition $(\%)^{1}$ & Cell viability $(\%)^{2}$ \\
\hline Blank & $12.8 \pm 1.7^{\mathrm{b}}$ & $20.7 \pm 8.1^{\mathrm{b}}$ & $75 \pm 3^{\mathrm{a}}$ & $16.0 \pm 0.2^{\mathrm{b}}$ & $13.5 \pm 16.3^{\mathrm{b}}$ & $56 \pm 2^{\mathrm{ab}}$ \\
Control & $11.1 \pm 0.2^{\mathrm{b}}$ & $-^{\mathrm{b}}$ & $79 \pm 2^{\mathrm{a}}$ & $16.3 \pm 0.4^{\mathrm{b}}$ & $-5^{\mathrm{b}}$ & $61 \pm 5^{\mathrm{a}}$ \\
$10 \mu \mathrm{g} / \mathrm{mL}$ & $12.8 \pm 0.3^{\mathrm{b}}$ & $89.6 \pm 5.1^{\mathrm{a}}$ & $24 \pm 5^{\mathrm{b}}$ & $18.5 \pm 0.1^{\mathrm{a}}$ & $95.1 \pm 2.5^{\mathrm{a}}$ & $53 \pm 7^{\mathrm{ab}}$ \\
$15 \mu \mathrm{g} / \mathrm{mL}$ & $18.4 \pm 0.2^{\mathrm{a}}$ & $99.8 \pm 0.1^{\mathrm{a}}$ & $27 \pm 4^{\mathrm{b}}$ & $19.3 \pm 0.2^{\mathrm{a}}$ & $99.8 \pm 0.1^{\mathrm{a}}$ & $35 \pm 4^{\mathrm{bc}}$ \\
$30 \mu \mathrm{g} / \mathrm{mL}$ & $19.0 \pm 0.3^{\mathrm{a}}$ & $100.0 \pm 0.1^{\mathrm{a}}$ & $29 \pm 6^{\mathrm{b}}$ & $19.1 \pm 0.4^{\mathrm{a}}$ & $100 \pm 0.0^{\mathrm{a}}$ & $13 \pm 3^{\mathrm{c}}$ \\
$P$ values & 0.0003 & $<0.0001$ & $<0.0001$ & $<0.0001$ & 0.0018 & 0.0004 \\
\hline
\end{tabular}

${ }^{\mathrm{a}-\mathrm{c}}$ Treatment means with unequal superscripts are different at $P<0.05$.

${ }^{1}$ Calculated from methane production rate $(\mu \mathrm{mol} / \mathrm{mg}$ cell DM/min) in percent of the value of the control group after 3 and $24 \mathrm{~h}$, respectively.

${ }^{2}$ Percentage of live cells (green) of total cells (green, yellow, and red) as determined with the LIVE/DEAD BacLight Kit.

of SFAs on the activity of cells and microorganisms [15]. However, studies on the effects of SFAs on pure cultures of ruminal methanogens are limited [12]. Although, finally, potential inhibitors of ruminal methanogenesis have to be evaluated with the mixed microbial community and in the presence of feeds, elucidating the SFA effects on individual methanogen species in the absence of further influencing factors is very important to differentiate direct and indirect SFA effects on methanogens and to identify the mechanisms which lead to the inhibition of methanogenesis by SFAs.

4.1. Efficiency of Saturated Fatty Acids to Inhibit Methanogenesis in Methanobrevibacter ruminantium. In the present 


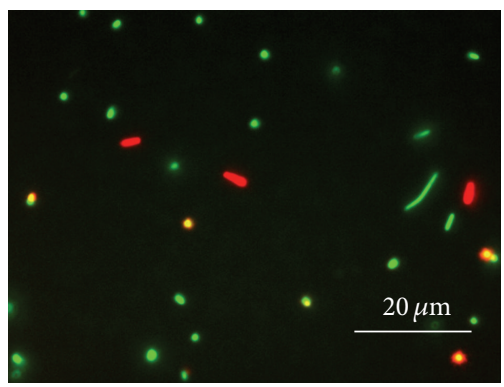

(a)

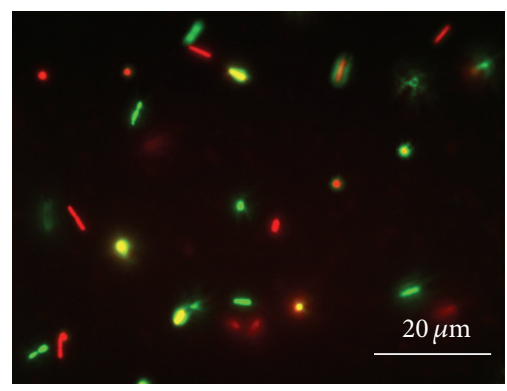

(d)

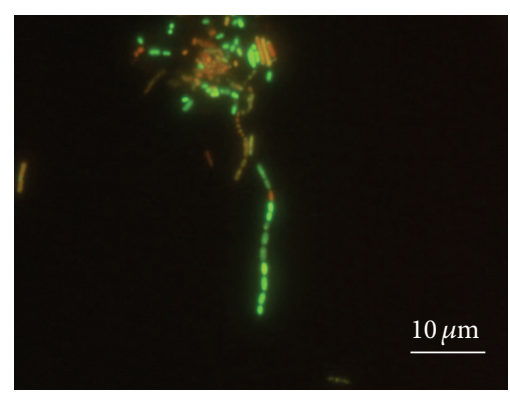

$(\mathrm{g})$

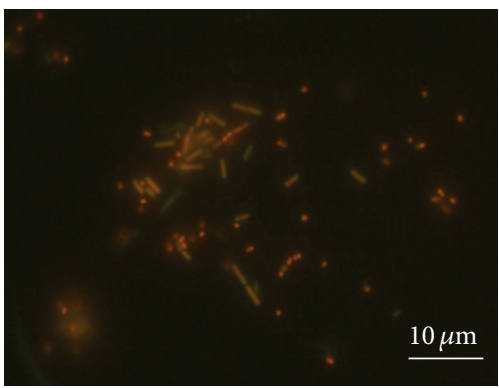

(j)

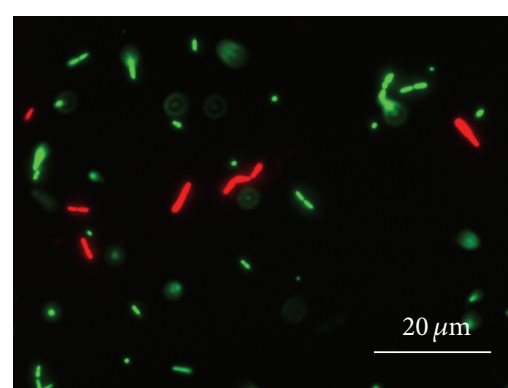

(b)

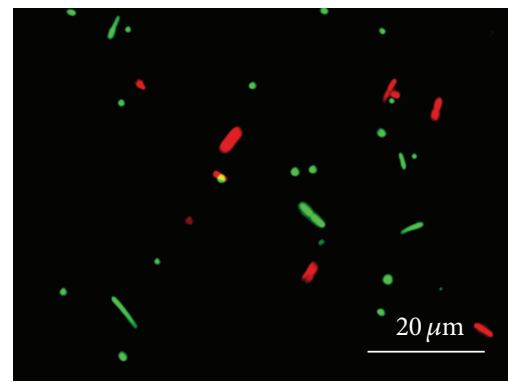

(e)

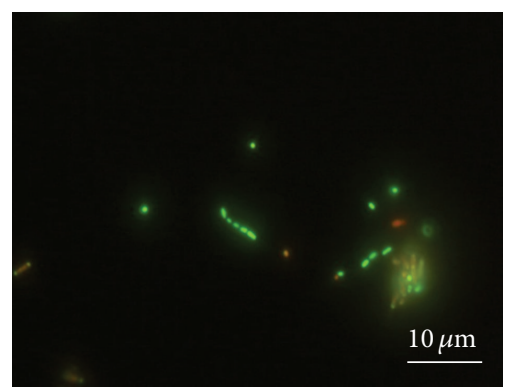

(h)

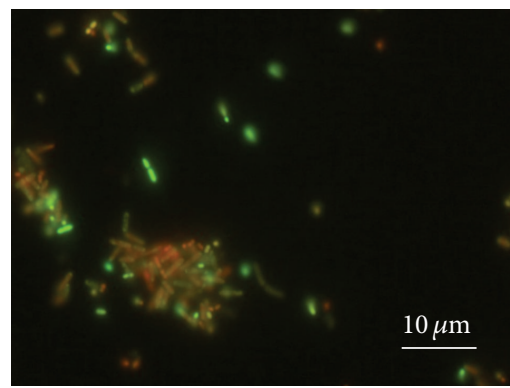

(k)

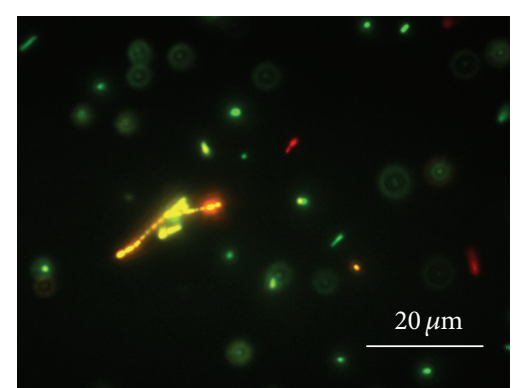

(c)

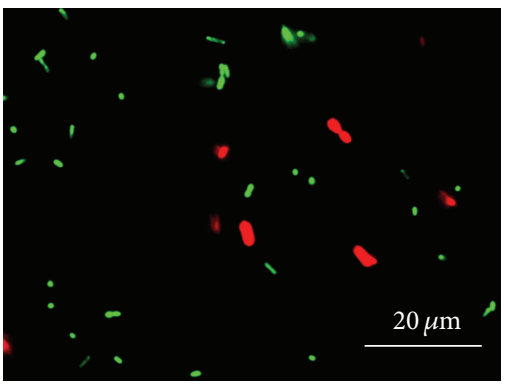

(f)

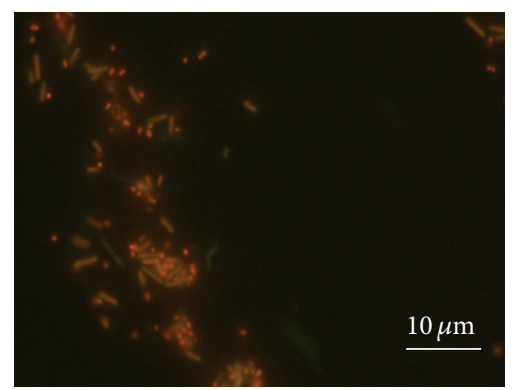

(i)

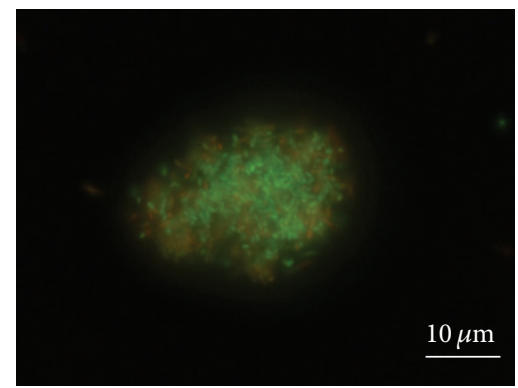

(1)

FIGURE 2: Fluorescence images illustrating cell viability of M. ruminantium cell suspensions exposed to different saturated fatty acids provided in a concentration of $10 \mu \mathrm{g} / \mathrm{mL}$ in $\mathrm{K}^{+}$-free buffer and stained with the LIVE/DEAD BacLight Kit (Experiment 3). Green and red cells represent living and dead cells, respectively. Yellow cells were not categorized as living but included in total cell counts. (a-f) Images taken $3 \mathrm{~h}$ after SFA supplementation; (g-l) Images taken after $24 \mathrm{~h}$. The images selected are representative for blank (a, g), control (b, h), $\mathrm{C}_{12}(\mathrm{c}, \mathrm{i}), \mathrm{C}_{14}(\mathrm{~d}, \mathrm{j}), \mathrm{C}_{16}$ $(\mathrm{e}, \mathrm{k})$, and $\mathrm{C}_{18}(\mathrm{f}, \mathrm{l})$.

study, at first the effect of SFAs on $\mathrm{CH}_{4}$ production by cell suspensions of a major ruminal methanogen, M. ruminantium, was examined. The inhibition of methanogenesis in washed cell suspensions of $M$. ruminantium was getting more pronounced with decreasing chain length $\left(\mathrm{C}_{12}=\mathrm{C}_{14}>\right.$ $\mathrm{C}_{16}>\mathrm{C}_{18}$ ) and increasing SFA concentration (1 to $80 \mu \mathrm{g} / \mathrm{mL}$ suspension) or SFA/cell DM ratio (0.2 to $13 \mu \mathrm{g} / \mathrm{mg}$ cell DM). Although cell inoculum each time was always applied by transferring the same volume using the microbes at almost the same growth phase and the cell suspensions were prepared by following the same protocol in each incubation, it seems that cell susceptibility varied between incubations, 
TABLE 2: Methane inhibition rate, $\mathrm{K}^{+}$efflux, and cell viability in cell suspensions treated with different saturated fatty acids at $10 \mu \mathrm{g} / \mathrm{mL}$ in Experiment 3 ( $n=3$; means \pm standard error).

\begin{tabular}{|c|c|c|c|c|c|c|}
\hline Time & & $3 \mathrm{~h}$ & & & $24 \mathrm{~h}$ & \\
\hline Treatment & $\mathrm{K}^{+}(\mathrm{mg} / \mathrm{L})$ & $\mathrm{CH}_{4}$ inhibition rate $(\%)^{1}$ & Cell viability $(\%)^{2}$ & $\mathrm{~K}^{+}(\mathrm{mg} / \mathrm{L})$ & $\mathrm{CH}_{4}$ inhibition rate $(\%)^{1}$ & Cell viability $(\%)^{2}$ \\
\hline Blank & $5.1 \pm 0.1^{\mathrm{d}}$ & $-6.8 \pm 3.5^{\mathrm{b}}$ & $79 \pm 7^{\mathrm{a}}$ & $14.2 \pm 0.3^{\mathrm{b}}$ & $-2.5 \pm 11.1^{\mathrm{b}}$ & $50 \pm 8^{\mathrm{a}}$ \\
\hline Control & $5.4 \pm 0.4^{\mathrm{d}}$ & $-{ }^{b}$ & $81 \pm 2^{\mathrm{a}}$ & $12.9 \pm 0.3^{\mathrm{b}}$ & $-{ }^{b}$ & $40 \pm 6^{\mathrm{a}}$ \\
\hline $\mathrm{C}_{12}$ & $13.8 \pm 0.2^{\mathrm{a}}$ & $99.9 \pm 0.0^{\mathrm{a}}$ & $43 \pm 2^{b}$ & $15.7 \pm 0.2^{\mathrm{a}}$ & $100 \pm 0.1^{\mathrm{a}}$ & $1 \pm 0^{\mathrm{b}}$ \\
\hline $\mathrm{C}_{14}$ & $13.9 \pm 0.2^{\mathrm{a}}$ & $99.8 \pm 0.2^{\mathrm{a}}$ & $36 \pm 5^{\mathrm{b}}$ & $15.7 \pm 0.3^{\mathrm{a}}$ & $100 \pm 0.0^{\mathrm{a}}$ & $3 \pm 1^{b}$ \\
\hline $\mathrm{C}_{16}$ & $8.7 \pm 0.2^{b}$ & $85.4 \pm 1.8^{\mathrm{a}}$ & $68 \pm 6^{\mathrm{a}}$ & $13.5 \pm 0.1^{\mathrm{b}}$ & $100 \pm 0.1^{\mathrm{a}}$ & $12 \pm 5^{\mathrm{b}}$ \\
\hline $\mathrm{C}_{18}$ & $7.0 \pm 0.1^{\mathrm{c}}$ & $7.9 \pm 17.6^{b}$ & $78 \pm 5^{\mathrm{a}}$ & $13.9 \pm 0.2^{\mathrm{b}}$ & $44 \pm 16.2^{\mathrm{ab}}$ & $38 \pm 5^{\mathrm{a}}$ \\
\hline$P$ values & $<0.0001$ & $<0.0001$ & $<0.0001$ & $<0.0001$ & 0.0015 & $<0.0001$ \\
\hline
\end{tabular}

${ }^{\mathrm{a}-\mathrm{d}}$ Treatment means with unequal superscripts are different at $P<0.05$.

${ }^{1}$ Calculated from methane production rate $(\mu \mathrm{mol} / \mathrm{mg}$ cell DM/min) in percent of the value of the control group after 3 and $24 \mathrm{~h}$, respectively.

${ }^{2}$ Percentage of live cells (green) of total cells (green, yellow, and red) as determined with the LIVE/DEAD BacLight Kit.

which also caused variability in the $\mathrm{CH}_{4}$ production patterns of the control groups (Figure 1 and Supplementary Figure 1). In agreement with studies performed at $35-38^{\circ} \mathrm{C}$ and neutral $\mathrm{pH}$ in cultures of ruminal and nonruminal methanogens and bacteria $[12,13,32]$ and in sheep in vivo [33], the present data also indicate that $\mathrm{C}_{12}$ and $\mathrm{C}_{14}$ are the most effective SFAs. $\mathrm{C}_{12}$ had also been the most inhibitory representative of the SFAs against 12 Gram-positive microorganisms [32]. In the present study, the hydrophobic SFAs were dissolved in DMSO to guarantee distribution of SFA in the hydrophilic $M$. ruminantium cell suspension. Nevertheless, despite using DMSO, the SFA solubility was visually observed to decrease as SFA chain length increased. Solubility was especially weak when using $\mathrm{C}_{18}$ at $37^{\circ} \mathrm{C}$ where also no $\mathrm{CH}_{4}$ inhibition occurred. $\mathrm{C}_{18}$ was only inhibitory at $50^{\circ} \mathrm{C}$, which corresponds with its increased solubility at this temperature. This supports the hypothesis that SFAs need to be at least partly dissolved in the buffer or medium to be able to exert an effect [13]. Further experiments have to investigate if the SFAs state (protonated versus dissociated) plays a role in $M$. ruminantium. Lowering the $\mathrm{pH}$ of the incubation medium has been shown to increase adsorption of SFAs onto bacteria and also their sensitivity against SFAs $[20,34]$. The SFA concentrations needed to achieve a $50 \%$ reduction in $\mathrm{CH}_{4}$ formation rates were much lower in the present study than those required in the study of Henderson [12], where $0.5 \mathrm{~g} / \mathrm{L}$ of $\mathrm{C}_{12}$ and $\mathrm{C}_{14}$ were necessary to reduce the growth rate of $M$. ruminantium by $50 \%$ compared to the control. This might have resulted either from the difference in metabolic state between cell cultures and cell suspensions or from differences in growth states before SFA supplementation and harvesting or both. Still, the SFA concentrations where a significant inhibition of methanogenesis occurred in the present study (10 to $80 \mu \mathrm{g} / \mathrm{mL}$ ) were in the same order of magnitude than those reported earlier (30 to $1000 \mu \mathrm{g} / \mathrm{mL}$ ) in growing methanogen cultures $[12,13,20$, 32]. This indicates that in cell cultures and cell suspensions generally the same type of effect occurs. Presumably, no cell growth occurred in the washed cell suspensions used due to the absence of nutrients needed for growth of $M$. ruminantium, like acetate and coenzyme $M$ [35], and, in case of K-containing buffer, also nitrogen. Therefore, only $\mathrm{CH}_{4}$ production, that is, energy metabolism, was performed which indicates that the SFAs directly affect the process of $\mathrm{CH}_{4}$ formation. Each dose-response test had been repeated at least once and in both incubations in three replicates each to allow robust conclusions. Although the extent of the inhibition of methanogenesis by the different SFA concentrations was not exactly the same in the two incubations, the ranking and inhibition extent of the treatments with regard to the level of effect were coinciding. Slight variations in $\mathrm{CH}_{4}$ formation rates and peak times as well as in the SFA effects might be due to slight differences in growth phase between incubations when the cells being in their mid-exponential phase were harvested.

4.2. Indications for Modes of Action of Saturated Fatty Acids. In the present study, the findings on $\mathrm{K}^{+}$leakage, an indicator of a damaged membrane [21], indicate that the cell membrane permeability increases after SFA exposure. The integrity of the archaeal membrane is fundamental to maintain the chemiosmotic balance, which is essential for the membraneassociated energetic metabolism of cells $[5,26]$. The $\mathrm{K}^{+}$ leakage also occurred concomitantly to the inhibition of methanogenesis which seems to have been followed by increasing occurrence of cell death. The $\mathrm{K}^{+}$efflux in $M$. ruminantium responded to different SFAs and to different $\mathrm{C}_{12}$ concentrations similarly as the $\mathrm{CH}_{4}$ production rate. Accordingly, $\mathrm{C}_{12}$ and $\mathrm{C}_{14}$ triggered the largest $\mathrm{K}^{+}$efflux and had the strongest inhibitory effects of all SFAs tested, and increasing $\mathrm{C}_{12}$ concentrations increasingly inhibited methanogenesis and promoted $\mathrm{K}^{+}$efflux compared to the lower dosages. The LIVE/DEAD BacLight bacterial viability kit has been already shown to be a useful tool to indicate cell viability in Archaea $[28,29]$. Although the $\mathrm{CH}_{4}$ production rate declined to zero, corroborated by heavy $\mathrm{K}^{+}$leakage, in treatment groups supplemented with $\mathrm{C}_{12}$ and $\mathrm{C}_{14}$ at $3 \mathrm{~h}$, and the percentage of cells with damaged membrane was significantly different to all other groups, it was not zero. It seems that cell death does not occur immediately but is delayed in time because after $24 \mathrm{~h}$, and the cells in these two groups were nearly all dead.

4.3. Conclusion. The inhibitory effect of SFAs on the production of the important greenhouse gas methane by 
M. ruminantium was demonstrated to be dependent on SFA concentration, SFA type, and incubation temperature $\left(37^{\circ} \mathrm{C}\right.$ versus $50^{\circ} \mathrm{C}$ ). The present study showed for the first time with a ruminal methanogen, $M$. ruminantium, that supplementation of SFAs can also damage the cell membrane and trigger $\mathrm{K}^{+}$efflux. The identification of the detailed mechanism on how SFAs are detrimental to the methanogens needs further studies.

\section{Conflict of Interests}

The authors declare that there is no conflict of interests.

\section{Acknowledgments}

The authors are very grateful to R. Thauer for his advice and helpful discussions and to B. Studer for potassium analysis. This study was supported by the China Scholarship Council.

\section{References}

[1] D. J. Wuebbles and K. Hayhoe, "Atmospheric methane and global change," Earth-Science Reviews, vol. 57, no. 3-4, pp. 177210, 2002.

[2] E. A. Scheehle and D. Kruger, "Global anthropogenic methane and nitrous oxide emissions," The Energy Journal, vol. 27, pp. 3344, 2006.

[3] P. H. Janssen and M. Kirs, "Structure of the archaeal community of the rumen," Applied Microbiology and Biotechnology, vol. 74, no. 12, pp. 3619-3625, 2008.

[4] T. A. McAllister and C. J. Newbold, "Redirecting rumen fermentation to reduce methanogenesis," Australian Journal of Experimental Agriculture, vol. 48, no. 2, pp. 7-13, 2008.

[5] R. K. Thauer, A. K. Kaster, H. Seedorf, W. Buckel, and R. Hedderich, "Methanogenic archaea: ecologically relevant differences in energy conservation," Nature Reviews Microbiology, vol. 6 , no. 8, pp. 579-591, 2008.

[6] K. A. Johnson and D. E. Johnson, "Methane emissions from cattle," Journal of Animal Science, vol. 73, no. 8, pp. 2483-2492, 1995.

[7] F. Dohme, A. Machmüller, A. Wasserfallen, and M. Kreuzer, "Ruminal methanogenesis as influenced by individual fatty acids supplemented to complete ruminant diets," Letters in Applied Microbiology, vol. 32, no. 1, pp. 47-51, 2001.

[8] A. Machmüller and M. Kreuzer, "Methane suppression by coconut oil and associated effects on nutrient and energy balance in sheep," Canadian Journal of Animal Science, vol. 79, no. 1, pp. 65-72, 1999.

[9] C. R. Soliva, L. Meile, I. K. Hindrichsen, M. Kreuzer, and A. Machmüller, "Myristic acid supports the immediate inhibitory effect of lauric acid on ruminal methanogens and methane release," Anaerobe, vol. 10, no. 5, pp. 269-276, 2004.

[10] C. M. Zhang, Y. Q. Guo, Z. P. Yuan et al., "Effect of octadeca carbon fatty acids on microbial fermentation, methanogenesis and microbial flora in vitro," Animal Feed Science and Technology, vol. 146, no. 3-4, pp. 259-269, 2008.

[11] R. A. Prins, C. J. Van Nevel, and D. I. Demeyer, "Pure culture studies of inhibitors for methanogenic bacteria," Antonie van Leeuwenhoek, vol. 38, no. 1, pp. 281-287, 1972.

[12] C. Henderson, "The effects of fatty acids on pure cultures of rumen bacteria," Journal of Agricultural Science, vol. 81, no. 1, pp. 107-112, 1973.
[13] J. O. Zeitz, S. Bucher, X. Zhou, L. Meile, M. Kreuzer, and C. R. Soliva, "Inhibitory effects of saturated fatty acids on methane production by methanogenic Archaea," Journal of Animal and Feed Science, vol. 22, no. 1, pp. 44-49, 2013.

[14] F. Dohme, A. Machmüller, A. Wasserfallen, and M. Kreuzer, "Comparative efficiency of various fats rich in medium-chain fatty acids to suppress ruminal methanogenesis as measured with RUSITEC," Canadian Journal of Animal Science, vol. 80, no. 3, pp. 473-482, 2000.

[15] A. P. Desbois and V. J. Smith, "Antibacterial free fatty acids: activities, mechanisms of action and biotechnological potential," Applied Microbiology and Biotechnology, vol. 85, no. 6, pp. 1629-1642, 2010.

[16] J. B. Parsons, J. Yao, M. W. Frank, P. Jackson, and C. O. Rock, "Membrane disruption by antimicrobial fatty acids releases lowmolecular-weight proteins from Staphylococcus aureus," Journal of Bacteriology, vol. 194, no. 19, pp. 5294-5304, 2012.

[17] K. Benkendorff, A. R. Davis, C. N. Rogers, and J. B. Bremner, "Free fatty acids and sterols in the benthic spawn of aquatic molluscs, and their associated antimicrobial properties," Journal of Experimental Marine Biology and Ecology, vol. 316, no. 1, pp. 29-44, 2005.

[18] F. C. Küpper, E. Gaquerel, E. M. Boneberg, S. Morath, J. P. Salaün, and P. Potin, "Early events in the perception of lipopolysaccharides in the brown alga Laminaria digitata include an oxidative burst and activation of fatty acid oxidation cascades," Journal of Experimental Botany, vol. 57, no. 9, pp. 1991-1999, 2006.

[19] F. Kamp, J. A. Hamilton, and H. V. Westerhoff, "Movement of fatty acids, fatty acid analogues, and bile acids across phospholipid bilayers," Biochemistry, vol. 32, no. 41, pp. 1107411086, 1993.

[20] H. Galbraith and T. B. Miller, "Effect of long chain fatty acids on bacterial respiration and amino acid uptake," Journal of Applied Bacteriology, vol. 36, no. 4, pp. 659-675, 1973.

[21] P. Boyaval, C. Corre, C. Dupuis, and E. Roussel, "Effects of free fatty acids on propionic acid bacteria," Lait, vol. 75, no. 1, pp. 17-29, 1995.

[22] L. L. Wang and E. A. Johnson, "Inhibition of Listeria monocytogenes by fatty acids and monoglycerides," Applied and Environmental Microbiology, vol. 58, no. 2, pp. 624-629, 1992.

[23] P. Tangwatcharin and P. Khopaibool, "Activity of virgin coconut oil, lauric acid or monolaurin in combination with lactic acid against Staphylococcus aureus," The Southeast Asian Journal of Tropical Medicine and Public Health, vol. 43, no. 4, pp. 969-985, 2012.

[24] G. Bergsson, J. Arnfinnsson, O. Steingrímsson, and H. Thormar, "Killing of Gram-positive cocci by fatty acids and monoglycerides," APMIS, vol. 109, no. 10, pp. 670-678, 2001.

[25] C. L. Fischer, D. R. Drake, D. V. Dawson, D. R. Blanchette, K. A. Brogden, and P. W. Wertz, "Antibacterial activity of sphingoid bases and fatty acids against Gram-positive and Gram-negative bacteria," Antimicrobial Agents and Chemotherapy, vol. 56, no. 3, pp. 1157-1161, 2012.

[26] S. V. Albers and B. H. Meyer, "The archaeal cell envelope," Nature Review Microbiology, vol. 9, no. 6, pp. 414-426, 2011.

[27] G. D. Sprott and K. F. Jarrell, " $\mathrm{K}^{+}, \mathrm{Na}^{+}$, and $\mathrm{Mg}^{2+}$ content and permeability of Methanospirillum hungatei and Methanobacterium thermoautotrophicum," Canadian Journal of Microbiology, vol. 27, no. 4, pp. 444-451, 1981.

[28] S. Leuko, A. Legat, S. Fendrihan, and H. Stan-Lotter, "Evaluation of the LIVE/DEAD BacLight kit for detection of 
extremophilic archaea and visualization of microorganisms in environmental hypersaline samples," Applied and Environmental Microbiology, vol. 70, no. 11, pp. 6884-6886, 2004.

[29] C. Bang, A. Schilhabel, K. Weidenbach et al., "Effects of antimicrobial peptides on methanogenic Archaea," Antimicrobial Agents and Chemotherapy, vol. 56, no. 8, pp. 4123-4130, 2012.

[30] H. J. Perski, J. Moll, and R. K. Thauer, "Sodium dependence of growth and methane formation in Methanobacterium thermoautotrophicum," Archives of Microbiology, vol. 130, no. 4, pp. 319-321, 1981.

[31] G. A. Jones and M. D. Pickard, "Effect of titanium (III) citrate as reducing agent on growth of rumen bacteria," Applied and Environmental Microbiology, vol. 39, no. 6, pp. 1144-1147, 1980.

[32] J. J. Kabara, D. M. Swieczkowski, A. J. Conley, and J. P. Truant, "Fatty acids and derivatives as antimicrobial agents," Antimicrobial Agents and Chemotherapy, vol. 2, no. 1, pp. 23-28, 1972.

[33] K. L. Blaxter and J. Czerkawski, "Modifications of the methane production of the sheep by supplementation of its diet," Journal of the Science of Food and Agriculture, vol. 17, no. 9, pp. 529-540, 1966.

[34] J. Yang, X. Hou, P. S. Mir, and T. A. McAllister, "Anti-Escherichia coli O157:H7 activity of free fatty acids under varying $\mathrm{pH}$," Canadian Journal of Microbiology, vol. 56, no. 3, pp. 263-267, 2010.

[35] C. D. Taylor, B. C. McBride, R. S. Wolfe, and M. P. Bryant, "Coenzyme M, essential for growth of a rumen strain of Methanobacterium ruminantium," Journal of Bacteriology, vol. 120, no. 2, pp. 974-975, 1974. 

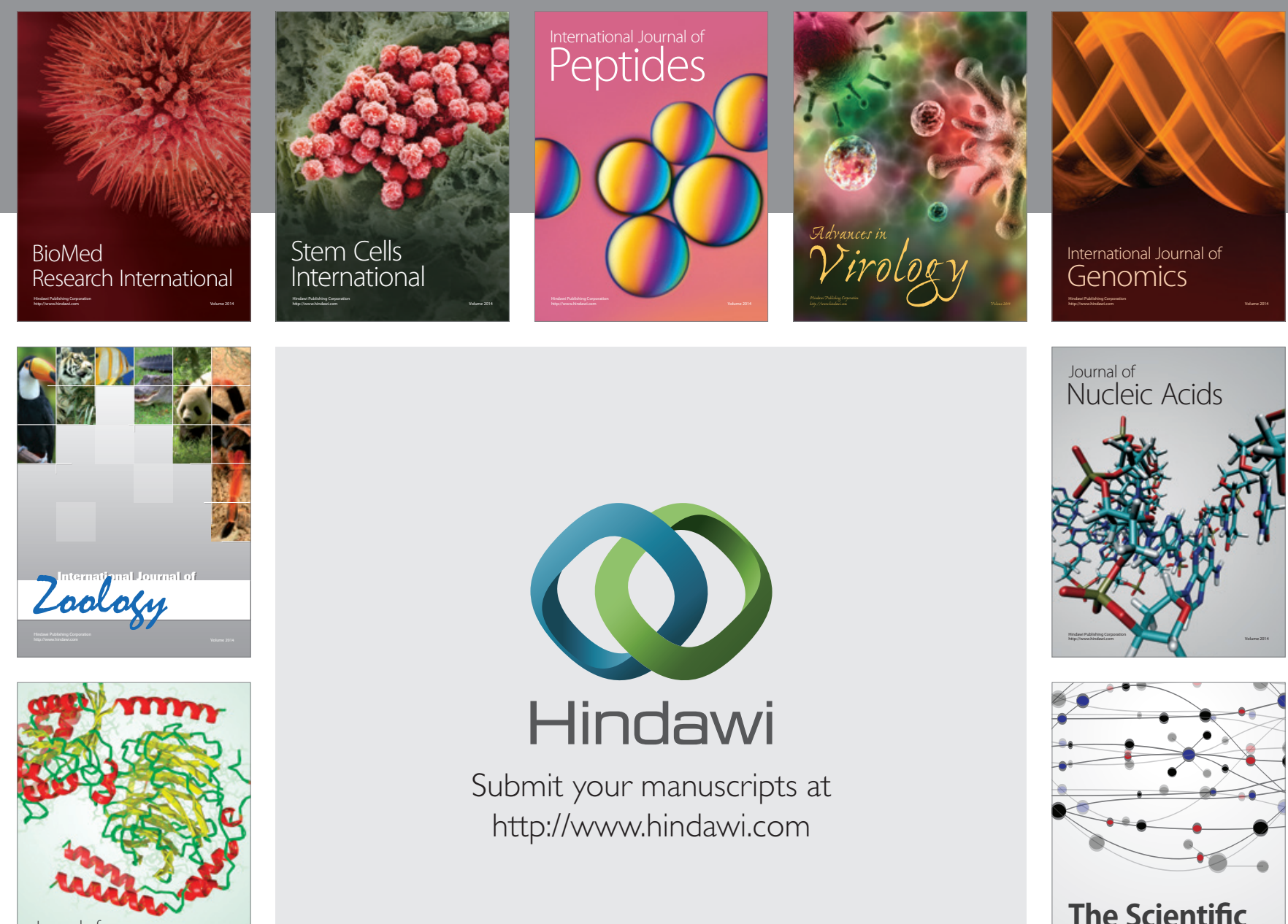

Submit your manuscripts at

http://www.hindawi.com

Journal of
Signal Transduction
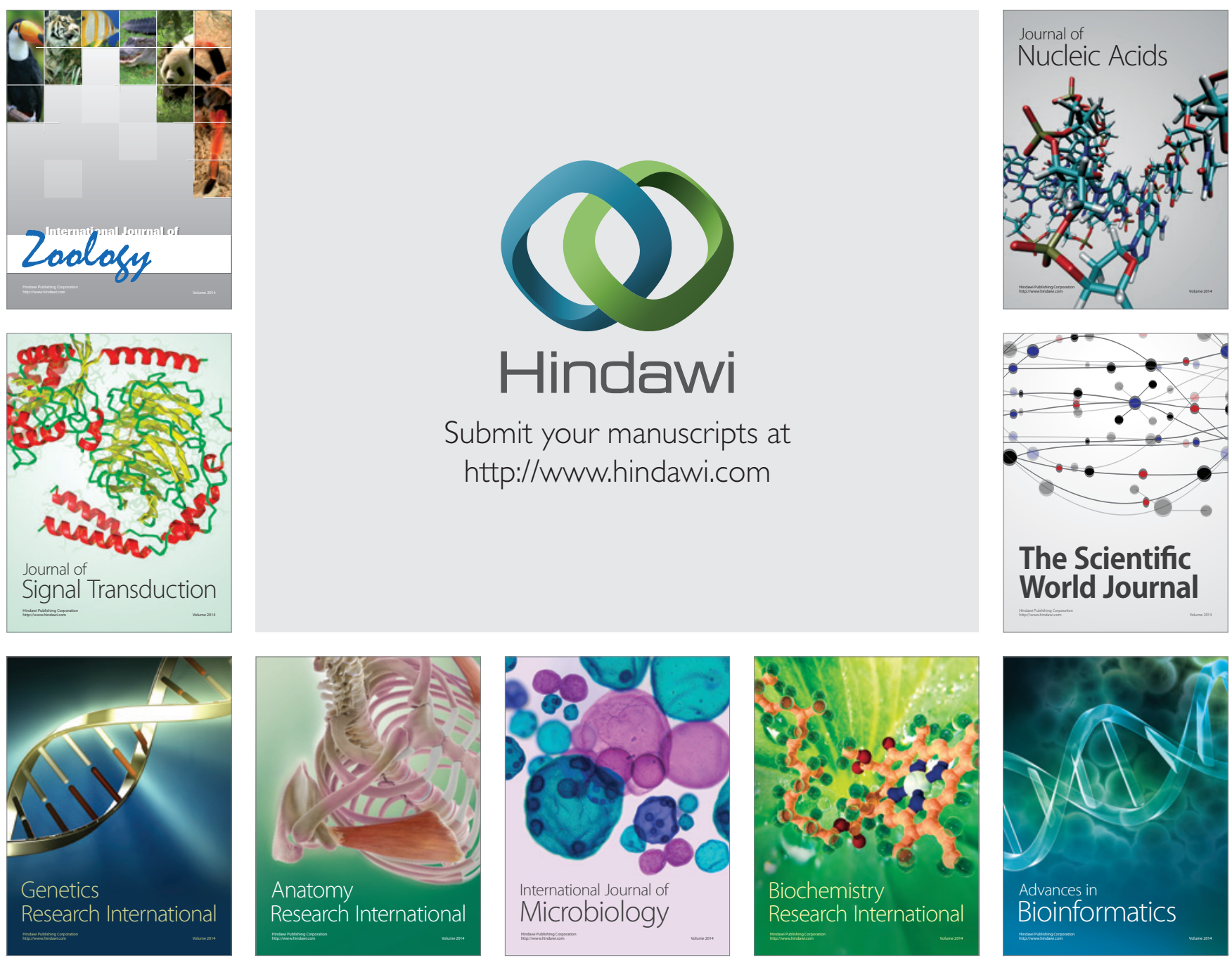

The Scientific World Journal
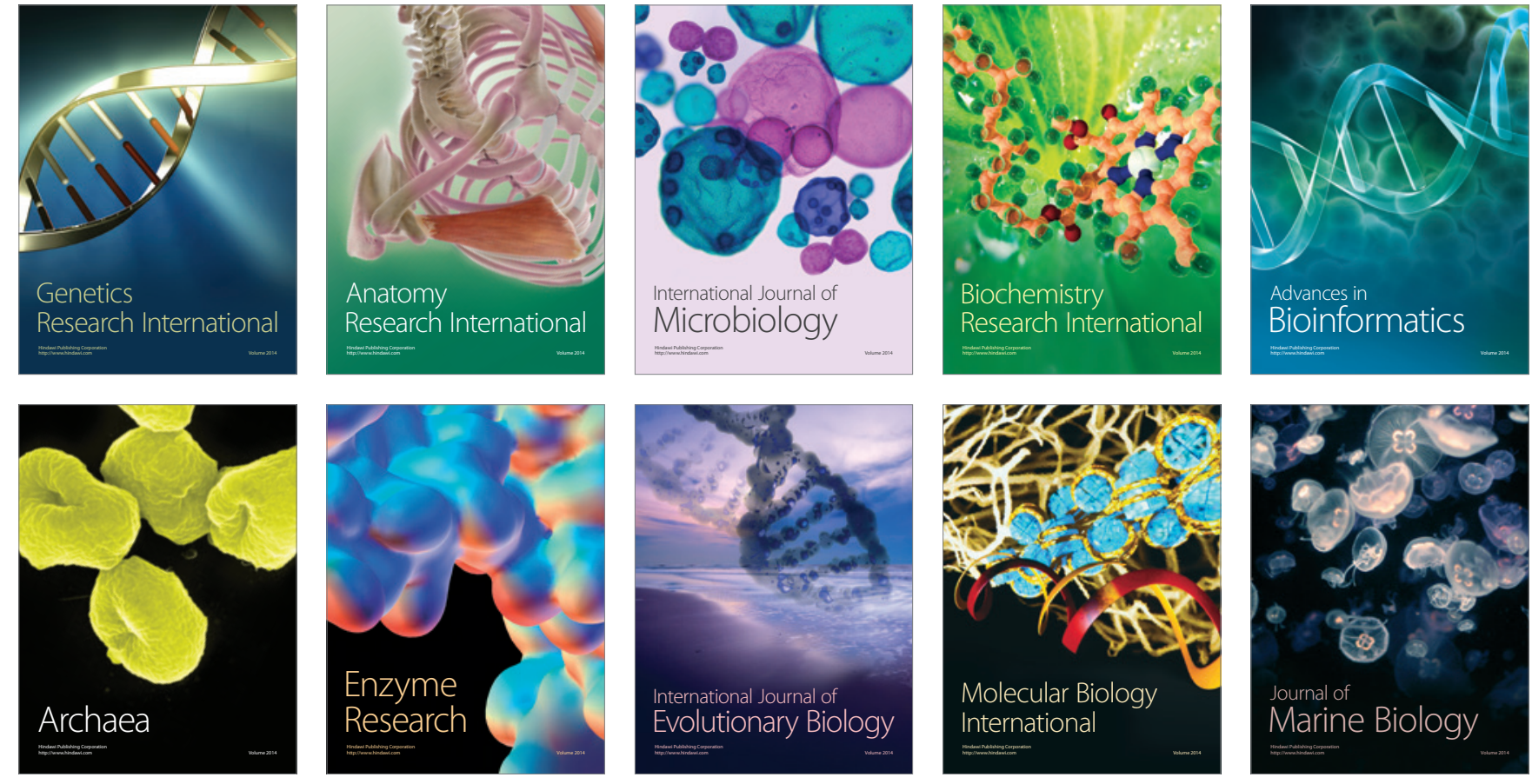